\title{
Deepening a Simple Question: Can MSCs Be Used to Treat Cancer?
}

\author{
JULIANA P.A. GOMES*, AMANDA F. ASSONI*, MAYRA PELATTI*, GIULIANA COATTI*, \\ OSWALDO KEITH OKAMOTO and MAYANA ZATZ \\ Human Genome and Stem Cell Research Center, Biosciences Institute, \\ University of Sao Paulo, Sao Paulo, Brazil
}

\begin{abstract}
In cancer, mesenchymal stem/stromal cells (MSCs) have been considered as vehicles for targeted delivery of drugs due to their inherent tropism toward primary and metastatic tumors. However, it is still unclear whether MSCs could be therapeutically explored without significant harm, since a great amound of evidence indicates that MSCs are able to exert both tumor-suppressive and pro-oncogenic effects. Here, we discuss how MSCs might adopt a pro- or anti-inflammatory profile in response to changes within the tumor microenvironment and how these features may lead to opposite outcomes in tumor development. Additionally, we address how differences in experimental design might impact interpretation and consistency of the current literature in this specific field. Finally, we point-out critical issues to be addressed at a preclinical stage, regarding safety and therapeutic effectiveness of MSCs application in cancer treatment.
\end{abstract}

Mesenchymal stem/stromal cells (MSCs) are undifferentiated multipotent cells with the ability to self-renew and differentiate into several distinct cell lineages $(1,2)$. They are composed of a heterogeneous population of cells, involved in the maintenance and repair of tissues throughout life. Since their first isolation from bone marrow samples, MSCs are also obtainable from different biological sources such as adipose tissue, umbilical cord, dental pulp and

This article is freely accessible online.

*These Authors contributed equally to this work.

Correspondence to: Mayana Zatz, Ph.D., Human Genome and Stem Cell Research Center, Biosciences Institute, University of São Paulo, Rua do Matāo 106, São Paulo CEP 05508-090, Brazil. Tel: +55 1130910880, e-mail: mayazatz@usp.br

Key Words: Mesenchymal stromal cells, cancer, immunomodulation, experimental design, therapy, review. fallopian tubes, among others (3-6). MSCs have been shown to derive from perivascular cells, known as pericytes, that are released from the basement membrane surrounding blood vessels upon injury or inflammation (7-9).

Pre-clinical studies support functional recovery after MSCs transplantation in diverse pathologies (10-15). Many of these studies show significant therapeutic benefits of cell transplantation even when exogenous cells are not present in the target tissues. This effect is predominantly associated with the release of soluble factors affecting diverse biological processes such as angiogenesis, apoptosis, and immune response $(13,16-22)$. Due to these paracrine effects, MSCs have been considered as "Medicinal Signaling Cells", delivering biological mediators to sites of injury or inflammation $(7,23)$.

MSCs are also emerging as promising targeted anticancer agents for the treatment of a number of different cancer types due to their inherent tumor-tropic migratory properties, which allow them to serve as vehicles for the effective delivery of drugs to primary tumors and metastatic sites. MSCs have already been engineered to express anti-proliferative, pro-apoptotic or anti-angiogenic agents that specifically target different cancer types (24, 25). For this purpose, transfection of MSCs using viral vectors is the most used strategy however, some new methods, such as the therapeutic ultrasound (TUS) are being proposed (26).

Although this engineered-MSCs approach may be promising, basic investigation of unmodified MSCs effects on tumor development is needed. MSCs from different biological sources have been evaluated in animal models of cancer, but discrepant results have been reported (27), either enhancing (28-30) or inhibiting tumor growth (31-33).

Therefore, in cancer, it is still unclear whether MSCs could be used in clinical studies without significant harm. In this review, we will focus on MSCs residents of the stroma and mainly on exogenous MSCs used as cell therapy. 


\section{MSCs Activity Within the Tumor Microenvironment}

It is known that MSCs can modulate their secretory profile depending on the composition of their microenvironment, i.e., their biological behavior is modified according to the factors that they are exposed to (34-39). The tumor microenvironment (TME) is a functional ecosystem of tumor, stromal elements and signaling molecules (40). The stroma is a histological unit consisting of peri-tumoral cells, including fibroblasts and MSCs, that actively interact with the tumor cells $(27,40-49)$.

As reviewed by Ridge and coworkers (50), MSCs are key players in cancer progression, as they can act in tumor development at various stages of progression from growth of the primary tumor to the establishment of distant metastasis. It was recently pointed-out that the presence of MSCs in 3D cancer spheroids promotes the formation of a stroma-like tissue surrounding the tumor supporting growth and increasing resistance to chemotherapy of liver colorectaltumor (51).

The bi-directional signaling between the cytokines secreted by malignant and non-malignant cells plays an important role in the establishment, progression, and metastatic dissemination of cancer (52-55).

TME is also rich in cytokines derived from immune system cells, such as tumor necrosis factor-alpha (TNF- $\alpha$ ), tumor growth factor-beta (TGF- $\beta$ ), interleukin 1 (IL-1) and interleukin 6 (IL-6), angiogenic factors, such as vascular endothelial growth factor (VEGF), and chemokines. As it is reviewed by de Visser and coworkers (56), TNF- $\alpha$ is a key cytokine that is mobilized during acute inflammation mediating tumor development. Knockout mice for TNF- $\alpha$ and its receptors have less susceptibility to skin cancer and develop fewer metastases. As TNF- $\alpha$ receptors are expressed in both stromal and epithelial cells, TNF- $\alpha$ facilitates the development of cancer directly by regulating the proliferation and survival of neoplastic cells, and indirectly by exerting its effects on endothelial cells, fibroblasts, and immune cells in the tumor microenvironment $(54,56,57)$. TNF- $\alpha$ was found to affect the permeability of the blood brain barrier and its increased expression was correlated with the development of brain metastasis in breast cancer patients (58).

TME can influence the activity of resident MSCs exchanging membrane proteins through nanotube structures and through soluble factor or exosomes containing micro RNA (40, 59-61). It has already been reported that in breast cancer, resident MSCs can migrate to the proximity of tumor foci, where they produce diverse cytokines such as IL-6, IL-8, monocyte chemoattractant protein-1 (MCP-1) and TGF- $\beta$, contributing to tumor growth (52). As reviewed by Bhome and coworkers (40), cancer-associated fibroblasts (CAFs) are responsible for the structural architecture of the tumor and at least $20 \%$ of CAFs originate from MSCs. MSCs differentiation to CAFs can be induced by either CAFs or tumor and recruitment is dependent on TGF-b and stromal cell-derived factor-1 (SDF-1), which stimulates growth, proliferation and invasion, angiogenesis and metastasis $(40,62)$.

The tumor cell mass is highly heterogeneous, which may be the key for its progression and adaptation to different treatment modalities, thus complicating personalizedmedicine strategies $(63,64)$. Among the different tumor cell types, cancer stem cells (CSCs) deserve special attention since they possess unique properties that are crucial for cancer progression to a more malignant state, including high efficiency to initiate and propagate tumors (65-70), and increased resistance to many kinds of chemical or physical insults (71). Cellular components of the TME, including MSCs and pericytes, have a critical role in the maintenance of a stem-like state in tumor cells, as well as in CSC selfrenewal (56).

\section{MSCs and Immune Response Against Cancer Cells}

The immune system has a natural capacity to detect and destroy abnormal cells, playing a major role in preventing tumor development. Despite that, tumor cells frequently adopt strategies to escape from immune cells, usually related to reduced antigen expression on their surface membrane and to induction of an immunosuppressive microenvironment (73-77).

In order to efficiently eliminate cancer cells, a great effort is being made to understand how cancer evades the immune system (78-82). In the past few years, significant progress has been made in immunotherapy strategies for cancer treatment. Different monoclonal antibodies, such as the MDX-010 (ipilimumab), which recognizes the cytotoxic T lymphocyte antigen-4 (CTLA-4), have been developed to boost the immune response against tumor cells. Treatment with MDX-010 was shown to increase Tcell function and antitumor responses in patients with advanced metastatic melanoma (83). Despite these positive results, significant toxicity was associated with this therapeutic approach, consisting mostly of inflammatory events in healthy body parts without cancerous cells (83).

Some cancerous cells also secrete programmed deathligand 1 (PD-L1) and programmed death-ligand 2 (PD-L2), which are able to interact with PD-1 receptor on T-cell surface, thus inhibiting T-cell activation and promoting tumor immune escape. Recently, a treatment with a novel human IgG4 PD-1 antibody (Nivolumab) increased overall survival in patients with squamous-cell lung carcinoma, in comparison with the conventional chemotherapy treatment. Nivolumab was reported efficient in disrupting PD-1- 
mediated signaling in T-cells, thereby restoring antitumor immunity (84-90).

MSCs possess immunosuppressive properties such as the ability to inhibit the differentiation of dendritic, B- and Tcells, attenuate natural killer (NK) cells, and also suppress regulatory T-cells (91-97). Therefore, possible oncogenic effects of MSCs have been considered in several MSC-based cell therapy protocols. The immunosuppressive potential of MSCs, however, is highly dependent on the composition of the microenvironment in which they are being stimulated. Waterman and coworkers (98) reported that stimulation of Toll-like receptors (TLR) TLR3 or TLR4 in MSCs may result in different secretory profiles, namely MSC1 and MSC2, mostly pro-inflammatory or immunosuppressive, respectively. These distinct profiles also support potential opposing effects of MSCs on cancer, either inhibiting (MSC1) or stimulating (MSC2) tumor growth (99).

The bi-modality of MSCs was also demonstrated by Chan and coworkers (100). It was reported that reduced levels of interferon- $\gamma$ (IFN- $\gamma)$ cause MSCs to express major histocompatibility complex class II (MHC-II) and ultimately act as antigen-presenting cells (APCs), stimulating inflammatory responses. When IFN- $\gamma$ is present in high levels, MHC-II expression is reduced, preventing MSCs to act as APCs and consequently inducing an immunosuppressive MSC phenotype. In another in vivo study, administration of colon cancer cells along with MSCs pre-stimulated with inflammatory cytokines IFN- $\gamma$ and TNF- $\alpha$, accelerated tumor growth in mice, compared to MSCs without pre-stimulation (101). Pre-treated MSCs showed higher expression levels of VEGF regulated via the hypoxia-inducible factor 1-alpha $(\mathrm{HIF}-1 \alpha)$ signaling pathway that enhanced tumor angiogenesis, finally leading to increased colon cancer growth $(101,102)$.

\section{MSCs’ Pro-Cancer Effect}

The cancer-associated stromal cells promote and regulate tumor growth, invasion and metastasis by the secretion of extracellular matrix components and growth factors $(29,103$, 104). Mi and coworkers (105) observed that even MSCs' conditioned media, due to IL-6 presence, was responsible to promote metastasis in hepatocellular carcinoma.

In a cell therapy context, transplanted MSCs might integrate within the cancer stroma and influence tumor development. The formation of new blood vessels is an important hallmark for tumor development (106). Following intravenous injections, it was observed that MSCs were able to home to tumor sites and assist the production of new tumor vessels $(107,108)$. It was also observed that MSCs were able to increase the proportion of CSCs in gastric carcinoma in vitro through activation of the WNT and TGF$\beta$ signaling pathways $(109,110)$.
Besides other immune cells, lymphocytes are also being investigated in cancer physiopathology. Recently, a correlation of high lymphocytic reaction with better prognosis in patients with solid colorectal cancer was reported (111). Therefore, when MSCs act as immunosuppressants, inhibiting T-cell proliferation, they might enhance cancer progression (111-116).

It was demonstrated that autologous or allogeneic MSCs might suppress the proliferation of naïve and memory $\mathrm{T}$ lymphocytes stimulated by alloantigen, mitogens, or T-cell co-receptors CD3 and CD28, in a mechanism independent of MHC recognition (117-123). This immunosuppressive property is maintained when MSCs and lymphocytes are separated by a semi-permeable membrane, pointing out the involvement of soluble factors that might vary according to the stimulating agent and the lymphocyte population used (whether full or sorted) $(121,124-131)$. Nevertheless, isolated extracellular vesicles derived from MSCs failed to suppress lymphocyte proliferation, suggesting that cell-cell contact also plays an important role on the immunosuppressive potential of MSCs (132) or indicating that the factors related to lymphocyte proliferation are not secreted through vesicles.

Similarly, MSCs inhibit the differentiation of naive and memory $\mathrm{CD}^{+} \mathrm{T}$-cells into Th17 precursors and might also inhibit naturally-occurring Th17 cells $(133,134)$. Human memory Th17 cells were found to suppress T-cell activation in breast cancer, suggesting that intratumoral Th17 cells contribute to cancer development and compromise anticancer therapy in breast cancer patients (135). Knockdown of interleukin-25 (IL-25) expression in MSCs abrogated Th17 suppression both in vitro and in vivo (136), highlighting the cytokine involvement in this process.

Epigenetic changes are also implicated in this process. It was previously observed that MSCs induced the production of IL-10 and the trimethylation of histone $\mathrm{H} 3$ lysine 4 at FOXP3 promoter in Th17 cells, leading to a higher capacity of these cells to inhibit in vitro proliferation of activated $\mathrm{CD}^{+}$T-cells (137). Also, MSCs provide maximal enhancement of regulatory T-cell function through direct cell-to-cell interaction mediated by the MSC membraneexpressed CD80 molecule (138).

Regarding B lymphocytes, some contradictory results are observed. It has been shown that MSCs could both increase or decrease proliferation and survival of these cells (139144). The mechanisms of action involve both contactdependent factors, such as PD-L1 and PD-L2, and soluble factors such as matrix metalloproteases. Though, these results depend on the source of $B$ lymphocyte and the experimental conditions used.

The effect of MSCs is also observed in elements of the innate immune system. MSCs have an inhibitory effect on NK cells, affecting different aspects of their function, such as proliferation, cytotoxicity, and cytokine production (145, 
146). Maturation and differentiation of dendritic cells (DC) are also influenced after co-culture with MSCs, mainly through prostaglandin E2 (PGE-2) action. Additionally, DC previously co-cultured with MSCs impaired allostimulation of $\mathrm{T}$ cells $(147,148)$.

\section{MSCs' Anticancer Effects}

Conversely, many studies have also shown that MSCs can suppress tumor growth $(149,150)$ (Figure 1). Despite low expression of MHC or costimulatory molecules by MSCs, it was hypothesized that allotransplantation of MSCs could elicit an immune response that would ultimately inhibit tumor growth $(149,151)$. Nevertheless, Khakoo and coworkers (32) showed that the inhibitory effect on tumor growth is due to an active role of MSCs: when human umbilical vein endothelial cells (HUVECs) were injected in a Kaposi's sarcoma model, no significant effect on tumor size was observed, while a significant tumor inhibition was observed in the same model after injection of MSCs.

MSCs may also suppress tumor growth due to an antiangiogenic effect $(152,153)$. MSCs migrate to the capillaries and position themselves between endothelial cells, resulting in defects in gap junctions. As a consequence, there is an increased production of reactive oxygen species, leading to endothelial cell apoptosis and subsequent degeneration of the capillaries. Thus, without the necessary supply of oxygen, the tumor stops growing.

Finally, some components of the MSCs' secretome can actively impair tumor growth. It has already been demonstrated that MSCs' conditioned medium can cause inhibition of tumor proliferation and induction of tumor cell death by cell cycle arrest and necrosis (31). Lu and coworkers (22) also reported induction of tumor cell death, but in this case, through apoptosis mediated by caspases and p21, instead of necrosis.

\section{Divergences on Experimental Design}

Studies aiming the evaluation of MSCs as a therapeutic approach for cancer use highly divergent methodologies, which might hinder a precise scientific understanding of the subject. In this section we discuss these differences and their implications. Selection of the appropriate MSC source, time and route of injection, experimental models, and number of injected cells are elements that must be taken into consideration when analyzing results.

\section{Source of MSCs}

Countless organs and tissues are now recognized as potential sources of MSCs. Each one provides a different microenvironment for its resident cells, acting on MSCs characteristics and regulating their migration and differentiation abilities. Therefore, MSCs obtained from different sources might have distinct biological properties and secretome patterns (154).

What is referred to as "mesenchymal stromal cells" is in fact a combination of different subpopulations of cells that possess similar immunophenotypic profiles and share the ability to differentiate into the three mesenchymal lineages. Most preclinical and clinical studies have been performed using a heterogeneous population of stromal cells (NCT02530047; NCT01983709; NCT02181478; NCT01275612), which could partly explain some contradictory results or even the lack of reproducibility.

In addition, allotransplantation or even xenotransplantation of MSCs in cancer animal models have shown inhibition of tumor development. It is imperative to determine if these results are due to the native pro-inflammatory effect of transplanted cells or if they are merely due to a non-self origin effect, with the exogenous cells eliciting an immune response and ultimately enhancing the activity of the host immune system to fight the tumor cells. On the other hand, in vitro and in vivo studies using syngeneic MSCs and tumor lineages showed important results in cancer inhibition in immunocompetent mice (152). Also, an active and straight role of MSCs might occur even if transplanted into immunodeficient mice (32). Nevertheless, some studies showed increased tumor growth after MSCs perfusion in immunocompetent or athymic mice $(28,155)$.

\section{Time and Route of Injection}

One of the most frequent procedures aiming to verify the effect of MSCs in tumor growth includes co-injection of both MSCs and tumor cells. In this regimen, distinct proportions of tumor cells and MSCs might interfere in the experiment outcome. Other experimental designs include injection of MSCs after the tumor establishment.

The impact of different timing of MSCs infusion was evaluated by Jazedje and coworkers (156). When MSCs were co-injected with murine breast cancer cells, the animals had a more severe course of the disease and displayed a reduced survival, while MSCs injected in mice already at the initial stage of mammary adenocarcinoma resulted in significant reduced tumor growth and also increased lifespan, as compared with control animals.

Moreover, MSCs can be transplanted through many routes such as subcutaneous or intravenous, and this variable might also impact the final outcome.

\section{Experimental Models}

Another issue to be considered is the species that tumor cells and MSCs are derived from. Many groups use human 


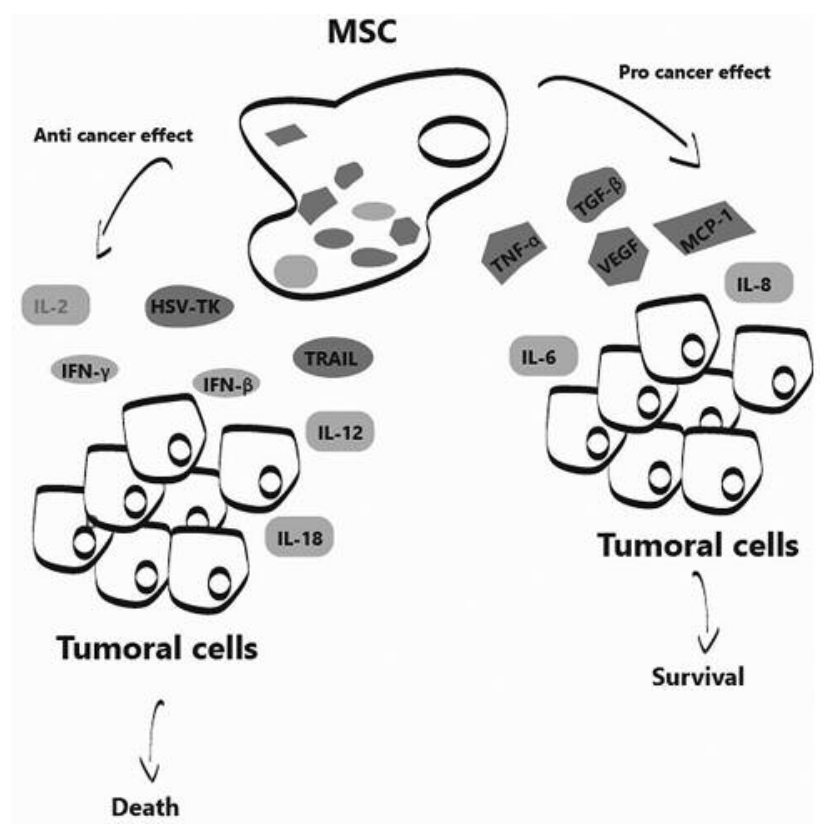

Figure 1. Pro and anti-cancer effect of mesenchymal stem stromal cells (MSCs). MSCs can produce pro or anti-cancer molecules, in response to the tumoral microenvironment, which can directly or indirectly affect the survival of cancer cells. MSCs have also been engineered to produce high amounts of anti-tumoral molecules (24). IL-6, interleukin 6; IL-8, interleukin 8;TNF- $\alpha$, tumor necrosis factor-alpha; TGF- $\beta$, tumor growth factor-beta; MCP-1, monocyte chemoattractant protein-1; IFN$\gamma$, Interferon- $\gamma ;$ IL-2, Interleukin-2; IL-12, Interleukin-12; IL-18, Interleukin-18; VEGF, Vascular Endothelial Growth Factor; TRAIL, TNF-Related Apoptosis-Inducing Ligand; HSV-TK, Herpes Simplex Virus-Thymidine Kinase.

tumoral cell lineages that consequently require an immunodeficient mouse model, otherwise, cancer cells could be recognized and destroyed by the host immune system. Since there is a lack of effective immune response, when MSCs are injected there are no proper interactions between these two components. Such studies are useful to understand the direct effect of MSCs on cancer but it is not sufficient to answer the question about MSCs' effects in cancer patients with a functional immune system.

There are also murine cell lineages of different tumors, which may have variability in their establishment or aggressiveness, thus responding differently to treatments. Cousin and coworkers (31) treated diverse tumor cell lines with adipose-derived stromal cells conditioned medium in vitro. Except for the cervical and breast cancer cell lines, MSCs-conditioned medium was able to inhibit tumor cell proliferation in pancreatic and other epithelial cancer-derived cell lines (liver, colon, prostate). These results demonstrated that different tumoral lineages may respond differently to a given treatment (31).

\section{Dose-dependence}

The effect of MSCs on cancer therapy also depends on the number of cells used. Long and coworkers (157), demonstrated by in vitro co-cultures that MSCs can generate a stimulatory or inhibitory effect on tumor growth, depending on the ratio between MSCs and cancer cells. When the proportion of MSCs was lower than the number of cancer cells, the later cells were able to proliferate. Respectively, when the proportion of MSCs was increased, the proliferation of cancer cells was reduced. Using fibroblasts, Delinasios and coworkers (46) studied early interactions, i.e. not fully-grown tumor, of stromal cells and cancer cells. It was shown the influence of cell confluence and also the HeLa: Fibroblasts ratio on in vitro cancer establishment.

These observations suggest that, in order to achieve successful results with MSC therapy, not only the amount of injected cells is important, but also the frequency of the injections. Khakoo and coworkers (32) demonstrated that, when a single dose of MSCs was injected intravenously concomitant to the subcutaneous injection of tumoral cells (day zero), tumor size was reduced. In the same study, three additional injections of MSCs were able to potentiate their effect on tumor growth inhibition. A similar effect was also observed when three MSCs injections were administered after tumor establishment.

\section{Concluding Remarks}

Despite the difficulty in comparing existing studies about the use of MSCs for cancer therapy, there is convincing evidence of both, tumor suppression and pro-oncogenic effects of MSCs. In any case, studies that investigate MSCs as anticancer agents should take into account real-life situations that cancer patients may experience. For instance, coinjection of tumoral cells and MSCs does not mimic a real clinical scenario. Instead, dose escalation studies of MSCs delivered systemically in tumor-bearing mice seem more suitable. In this pre-clinical setting, other important variables should be tested, including the frequency of MSCs injections and the type of MSCs. In the latter case, potency tests should also be developed to discriminate MSCs populations with the appropriate activity for a desirable anti-tumor effect. It has been observed that MSCs secrete different proteins even when they are obtained from the same tissue of different donors or from different tissues of the same donor (158). Additionally, MSCs activity is known to decline with donor's age (159). It would be interesting to determine a secretome profile of MSCs that best suits cancer therapy purposes, as Ranganath and coworkers (160) reviewed for ischemic heart failure.

Similarly, for the investigation of possible pro-oncogenic effects of MSCs, different MSCs/tumor cell ratios should be 
evaluated, mimicking different stages of tumor development. Moreover, orthotopic tumor models using MSCs of corresponding biological residence are more informative, given the differences in the tumor microenvironment among tissues. Noteworthy, variations in the constitution of the tumor microenvironment occur along the disease progression $(63,161)$, and the effects of such variations on the activity of MSCs should be clarified. The use of the appropriate cellular controls is another important issue to be considered. Injection of differentiated cells from the same biological source, such as fibroblasts, would indicate whether the effect on tumor development is a specific property of MSCs. Likewise, when human MSCs are used in murine models, injections of syngeneic murine MSCs would provide evidence that observed effects are not due to an interspecies artifact.

Besides the risk of increasing tumor size and tumorigenicity, there is the risk of MSCs injection itself. Safety of MSCs transplantation has already been reported by several studies, using MSCs from various sources in different diseases (162-165), but others have shown side effect, such as fibrosis, nausea, vomiting, increase of respiratory rate and pulmonary edema (166-168). Therefore, these reports highlight the importance of using well characterized MSCs.

Overall, studies addressing the role of MSCs in tumor development are equally important and the ensuing complementary knowledge is critical to evaluate possible applications of MSCs to treat cancer patients. The approach hereby proposed for pre-clinical studies should yield valuable information to support the elaboration of future clinical protocols.

\section{Disclosures}

The Authors disclose no potential conflicts of interest.

\section{Acknowledgements}

The collaboration of the following persons is gratefully acknowledged: Constância Gotto, Vanessa Sato, Wagner Falciano. This work was supported by CEPID/FAPESP (2013/08028-1), INCT (2008/57899-7 and 573633/2008-8) and CNPq (303393/2014-9).

\section{References}

1 Dominici M, Le Blanc K, Mueller I, Slaper-Cortenbach I, Marini F, Krause D, Deans R, Keating A, Prockop D and Horwitz E: Minimal criteria for defining multipotent mesenchymal stromal cells. The International Society for Cellular Therapy position statement. Cytotherapy 8: 315, 2006.

2 Pittenger M, Mackay A, Beck S, Jaiswal R, Douglas R, Mosca J, Moorman M, Simonetti D, Craig S and Marshak D: Multilineage potential of adult human mesenchymal stem cells. Science 284: 143-147, 1999.
3 Bianco P, Riminucci M, Gronthos S and Robey PG: Bone marrow stromal stem cells: nature, biology, and potential applications. Stem Cells 19: 180-192, 2001.

4 Secco M, Zucconi E, Vieira NM, Fogaça LLQ, Cerqueira A, Carvalho MDF, Jazedje T, Okamoto OK, Muotri AR and Zatz M: Multipotent stem cells from umbilical cord: cord is richer than blood! Stem Cells 26: 146-150, 2008.

5 Gronthos S, Brahim J, Li W, Fisher LW, Cherman N, Boyde A, DenBesten P, Robey PG and Shi S: Stem Cell Properties of Human Dental Pulp Stem Cells. J Dent Res 81: 531-535, 2002.

6 Zuk PA: The adipose-derived stem cell: looking back and looking ahead. Mol Biol Cell 21: 1783, 2010.

7 Caplan AI and Sorrell JM: The MSC curtain that stops the immune system. Immunol Lett 168: 136-139, 2015.

8 Corselli M, Chen C-W, Crisan M, Lazzari L and Péault B: Perivascular ancestors of adult multipotent stem cells. Arterioscler Thromb Vasc Biol 30: 1104, 2010.

9 Crisan M, Yap S, Casteilla L, Chen C-W, Corselli M, Park TS, Andriolo G, Sun B, Zheng B, Zhang L, Norotte C, Teng P-N, Traas J, Schugar R, Deasy BM, Badylak S, Buhring H-J, Giacobino J-P, Lazzari L, Huard J and Péault B: A perivascular origin for mesenchymal stem cells in multiple human organs. Cell Stem Cell 3: 301-313, 2008.

10 Ribeiro C a, Fraga JS, Grãos M, Neves NM, Reis RL, Gimble JM, Sousa N and Salgado AJ: The secretome of stem cells isolated from the adipose tissue and Wharton jelly acts differently on central nervous system derived cell populations. Stem Cell Res Ther 3: 18, 2012.

11 Shen Q, Chen B, Xiao Z, Zhao L, Xu X, Wan X, Jin M, Dai J and Dai $\mathrm{H}$ : Paracrine factors from mesenchymal stem cells attenuate epithelial injury and lung fibrosis. Mol Med Rep 11: 2831, 2015.

12 Zucconi E, Vieira NM, Bueno CR, Secco M, Jazedje T, Costa Valadares M, Fussae Suzuki M, Bartolini P, Vainzof M and Zatz M: Preclinical studies with umbilical cord mesenchymal stromal cells in different animal models for muscular dystrophy. J Biomed Biotechnol 2011: 715251, 2011.

13 Kinnaird T, Stabile E, Burnett MS, Shou M, Lee CW, Barr S, Fuchs $S$ and Epstein SE: Local delivery of marrow-derived stromal cells augments collateral perfusion through paracrine mechanisms. Circulation 109: 1543, 2004.

14 den Haan MC, van Zuylen V-L, Pluijmert NJ, Schutte CI, Fibbe WE, Schalij MJ, Roelofs H and Atsma DE: Discrepant results of experimental human mesenchymal stromal cell therapy after myocardial infarction: are animal models robust enough? PLoS One 11: e0152938, 2016.

15 Ciavarella S, Caselli A, Tamma AV, Savonarola A, Loverro G, Paganelli R, Tucci M and Silvestris F: A peculiar molecular profile of umbilical cord-mesenchymal stromal cells drives their inhibitory effects on multiple myeloma cell growth and tumor progression. Stem Cells Dev 24: 1457, 2015.

16 Chen J, Park H-C, Addabbo F, Ni J, Pelger E, Li H, Plotkin M and Goligorsky MS: Kidney-derived mesenchymal stem cells contribute to vasculogenesis, angiogenesis and endothelial repair. Kidney Int 74: 879-889, 2008.

17 Deans RJ and Moseley AB: Mesenchymal stem cells: biology and potential clinical uses. Exp Hematol 28: 875-884, 2000.

18 Estrada R, Li N, Sarojini H, An J, Lee M-J and Wang E: Secretome from mesenchymal stem cells induces angiogenesis via Cyr61. J Cell Physiol 219: 563-571, 2009. 
19 Gnecchi M, Danieli P and Cervio E: Mesenchymal stem cell therapy for heart disease. Vascul Pharmacol 57: 48-55, 2012.

20 Huang W-H, Chang M-C, Tsai K-S, Hung M-C, Chen H-L and Hung S-C: Mesenchymal stem cells promote growth and angiogenesis of tumors in mice. Oncogene 32: 4343-4354, 2013.

21 Kinnaird T, Stabile E, Burnett MS and Epstein SE: Bonemarrow-derived cells for enhancing collateral development: mechanisms, animal data, and initial clinical experiences. Circ Res 95: 354-363, 2004.

22 Lu Y, Yuan Y, Wang X, Wei L, Chen Y, Cong C, Li S, Long D, Tan W, Mao Y, Zhang J, Li Y and Cheng J: The growth inhibitory effect of mesenchymal stem cells on tumor cells in vitro and in vivo. Cancer Biol Ther 7: 245-251, 2008.

23 Trounson A, Thakar RG, Lomax G and Gibbons D: Clinical trials for stem cell therapies. BMC Med 9: 52, 2011.

24 Shah K: Mesenchymal stem cells engineered for cancer therapy. Adv Drug Deliv Rev 64: 739-748, 2012.

25 Mohammadi M, Jaafari MR, Mirzaei HR and Mirzaei H: Mesenchymal stem cell: a new horizon in cancer gene therapy. Cancer Gene Ther 23: 285, 2016.

26 Haber T, Baruch L and Machluf M: Ultrasound-Mediated mesenchymal stem cells transfection as a targeted cancer therapy platform. Sci Rep 7: 42046, 2017.

27 Hernanda PY, Pedroza-Gonzalez A, Sprengers D, Peppelenbosch MP and Pan Q: Multipotent mesenchymal stromal cells in liver cancer: Implications for tumor biology and therapy. Biochim Biophys Acta - Rev Cancer 1846: 439-445, 2014.

28 Djouad F, Plence P, Bony C, Tropel P, Apparailly F, Sany J, Noël D and Jorgensen C: Immunosuppressive effect of mesenchymal stem cells favors tumor growth in allogeneic animals. Blood 102: 3837-3844, 2003.

29 Karnoub AE, Dash AB, Vo AP, Sullivan A, Brooks MW, Bell GW, Richardson AL, Polyak K, Tubo R and Weinberg RA: Mesenchymal stem cells within tumour stroma promote breast cancer metastasis. Nature 449: 557-563, 2007.

30 Okumura T, Wang SSW, Takaishi S, Tu SP, Ng V, Ericksen RE, Rustgi AK and Wang TC: Identification of a bone marrowderived mesenchymal progenitor cell subset that can contribute to the gastric epithelium. Lab Invest 89: 1410-1422, 2009.

31 Cousin B, Ravet E, Poglio S, De Toni F, Bertuzzi M, Lulka H, Touil I, André M, Grolleau J-L, Péron J-M, Chavoin J-P, Bourin P, Pénicaud L, Casteilla L, Buscail L and Cordelier P: Adult stromal cells derived from human adipose tissue provoke pancreatic cancer cell death both in vitro and in vivo. PLoS One 4: e6278, 2009.

32 Khakoo AY, Pati S, Anderson S a, Reid W, Elshal MF, Rovira II, Nguyen AT, Malide D, Combs C a, Hall G, Zhang J, Raffeld M, Rogers TB, Stetler-Stevenson W, Frank J a, Reitz M and Finkel T: Human mesenchymal stem cells exert potent antitumorigenic effects in a model of Kaposi's sarcoma. J Exp Med 203: 1235-1247, 2006.

33 Sun B, Roh K-H, Park J-R, Lee S-R, Park S-B, Jung J-W, Kang S-K, Lee Y-S and Kang K-S: Therapeutic potential of mesenchymal stromal cells in a mouse breast cancer metastasis model. Cytotherapy 11: 289-298, 2009.

34 Alfaro C, Teijeira A, Oñate C, Perez G, Fernandez de Sanmamed M, Andueza MP, Alignani D, Labiano S, Azpilikueta A, Rodriguez-Paulete A, Garasa S, Fusco JP, Aznar
MA, Inoges S, Medina-Echeverz J, Berraondo P, Perez-Gracia $\mathrm{JL}$ and Melero I: Tumor-produced interleukin-8 attracts human myeloid-derived suppressor cells and elicits extrusion of neutrophil extracellular traps (NETs). Clin Cancer Res 22: 3924-3936, 2016.

35 Geginat J, Larghi P, Paroni M, Nizzoli G, Penatti A, Pagani M, Gagliani N, Meroni P, Abrignani S and Flavell RA: The light and the dark sides of Interleukin-10 in immune-mediated diseases and cancer. Cytokine Growth Factor Rev 30: 87-93, 2016.

36 Jafarzadeh A, Minaee K, Farsinejad A-R, Nemati M, Khosravimashizi A, Daneshvar H, Mohammadi MM, Sheikhi A and Ghaderi A: Evaluation of the circulating levels of IL-12 and IL-33 in patients with breast cancer: influences of the tumor stages and cytokine gene polymorphisms. Iran J Basic Med Sci 18: 1189-1198, 2015.

37 Kurimoto R, Iwasawa S, Ebata T, Ishiwata T, Sekine I, Tada Y, Tatsumi K, Koide S, Iwama A and Takiguchi Y: Drug resistance originating from a TGF- $\beta / F G F-2$-driven epithelial-tomesenchymal transition and its reversion in human lung adenocarcinoma cell lines harboring an EGFR mutation. Int J Oncol 48: 1825-1836, 2016.

38 Liu C-J, Kuo F-C, Wang C-L, Kuo C-H, Wang SSW, Chen CY, Huang Y-B, Cheng K-H, Yokoyama KK, Chen C-L, Lu C-Y and Wu D-C: Suppression of IL-8-Src signalling axis by $17 \beta-$ estradiol inhibits human mesenchymal stem cells-mediated gastric cancer invasion. J Cell Mol Med 20: 962-972, 2016.

39 Oh SK, Choi KH, Yoo JY, Kim DY, Kim SJ and Jeon SR: A Phase III Clinical Trial Showing Limited Efficacy of Autologous Mesenchymal Stem Cell Therapy for Spinal Cord Injury. Neurosurgery 78: 436-447, 2016.

40 Bhome R, Bullock MD, Al Saihati HA, Goh RW, Primrose JN, Sayan AE and Mirnezami AH: A top-down view of the tumor microenvironment: structure, cells and signaling. Front Cell Dev Biol 3: 1-9, 2015.

41 Alkasalias T, Flaberg E, Kashuba V, Alexeyenko A, Pavlova T, Savchenko A, Szekely L, Klein G and Guven H: Inhibition of tumor cell proliferation and motility by fibroblasts is both contact and soluble factor dependent. Proc Natl Acad Sci 111: 17188-17193, 2014.

42 Kennelly H, Mahon BP and English K: Human mesenchymal stromal cells exert HGF dependent cytoprotective effects in a human relevant pre-clinical model of COPD. Sci Rep 6: 38207, 2016.

43 Coulson-Thomas VJ, Gesteira TF, Coulson-Thomas YM, Vicente CM, Tersariol ILS, Nader HB and Toma L: Fibroblast and prostate tumor cell cross-talk: Fibroblast differentiation, TGF-b, and extracellular matrix down-regulation. Exp Cell Res 316: 3207-3226, 2010.

44 Hakelius M, Reyhani V, Rubin K and Gerdin B: Normal oral keratinocytes and head and neck squamous carcinoma cells induce an innate response of fibroblasts. Anticancer 2138: 2131-2137, 2016.

45 Trivanovic D, Krstic J, Djordjevic IO, Mojsilovic S, Santibanez JF, Bugarski D and Jaukovic A: The Roles of mesenchymal stromal/stem cells in tumor microenvironment associated with inflammation. Mediators Inflamm 2016: 7314016, 2016.

46 Delinasios JG, Angeli F, Koumakis G, Kumar S, Kang WH, Sica G, Iacopino F, Lama G, Lamprecht S, Sigal-Batikoff I, Tsangaris GT, Farfarelos CD, Farfarelos MC, Vairaktaris E, 
Vassiliou S and Delinasios GJ: Proliferating fibroblasts and HeLa cells co-cultured in vitro reciprocally influence growth patterns, protein expression, chromatin features and cell survival. Anticancer Res 35: 1881-1916, 2015.

47 Majety M, Pradel LP, Gies M and Ries CH: Fibroblasts influence survival and therapeutic response in a $3 \mathrm{D}$ co-culture model. PLoS One 10: 1-18, 2015.

48 Jones S, Horwood N, Cope A and Dazzi F: The Antiproliferative effect of mesenchymal stem cells is a fundamental property shared by all stromal cells. J Immunol 179: 2824-2831, 2007.

49 Linde N, Fluegan G and Aguirre-Ghiso JA: The Relationship between dormant cancer cells and their microenvironment. Adv Cancer Res 1848: 45-71, 2016.

50 Ridge SM, Sullivan FJ and Glynn SA: Mesenchymal stem cells: key players in cancer progression. Mol Cancer 16: 31, 2017.

51 Devarasetty M, Wang E, Soker S and Skardal A: Mesenchymal stem cells support growth and organization of host-liver colorectal-tumor organoids and possibly resistance to chemotherapy. Biofabrication 9: 21002, 2017.

52 Senst C, Nazari-Shafti T, Kruger S, Bentrup KHZ, Dupin CL, Chaffin AE, Srivastav SK, Wörner PM, Abdel-Mageed AB, Alt EU and Izadpanah R: Prospective dual role of mesenchymal stem cells in breast tumor microenvironment. Breast Cancer Res Treat 137: 69-79, 2013.

53 Gonzalez-Gugel E, Saxena M and Bhardwaj N: Modulation of innate immunity in the tumor microenvironment. Cancer Immunol Immunother 65: 1261, 2016.

54 Frediani JN and Fabbri M: Essential role of miRNAs in orchestrating the biology of the tumor microenvironment. Mol Cancer 15: 42, 2016.

55 Bose A, Ghosh T and Baral R: An overlooked tumor promoting immunoregulation by non-hematopoietic stromal cells. Immunol Lett 176: 114-121, 2016.

56 de Visser KE, Eichten A and Coussens LM: Paradoxical roles of the immune system during cancer development. Nat Rev Cancer 6: 24-37, 2006.

57 Chen W, Zhou S, Mao L, Zhang H, Sun D, Zhang J, Li Ji and Tang J-H: Crosstalk between TGF- $\beta$ signaling and miRNAs in breast cancer metastasis. Tumour Biol 37: 10011, 2016.

58 Xing F, Sharma S, Liu Y, Mo Y-Y, Wu K, Zhang Y-Y, Pochampally R, Martinez LA, Lo H-W and Watabe K: miR-509 suppresses brain metastasis of breast cancer cells by modulating RhoC and TNF- $\alpha$. Oncogene 34: 4890-4900, 2015.

59 Yang Y, Otte A and Hass R: Human mesenchymal stroma/stem cells exchange membrane proteins and alter functionality during interaction with different tumor cell lines. Stem Cells Dev 24: 1205-1222, 2015.

60 Spees JL, Lee RH and Gregory CA: Mechanisms of mesenchymal stem/stromal cell function. Stem Cell Res Ther: 1-13, 2016.

61 Malley GO, Heijltjes M, Houston AM, Rani S, Ritter T, Egan LJ and Ryan AE: Mesenchymal stromal cells (MSCs) and colorectal cancer - a troublesome twosome for the anti-tumour immune response? Oncotarget 7: 60752-60774, 2016.

62 Miles FL and Sikes RA: Insidious Changes in Stromal Matrix Fuel Cancer Progression. Mol Cancer Res 12: 297-312, 2014.

63 Gerlinger M, Rowan A, Horswell S, Larkin J, Endesfelder D, Math D, Gronroos E, Ph D, Martinez P, Matthews N, Sc B, Stewart A, Sc M, Tarpey P, Varela I, Phillimore B, Begum S,
Mcdonald NQ, Butler A, Jones D, Raine K, Latimer C, Santos CR, Nohadani M, Eklund AC, Spencer-dene B, Clark G, Pickering L, Stamp G, Gore M, Szallasi Z, Downward J, Futreal PA and Swanton C: Intratumor heterogeneity and branched evolution revealed by multiregion sequencing. $\mathrm{N}$ Engl J Med 366: 883-892, 2012.

64 Simon R and Roychowdhury S: Implementing personalized cancer genomics in clinical trials. Nat Rev Drug Discov 12: 358-369, 2013.

65 Lawson DA, Bhakta NR, Kessenbrock K, Prummel KD, Yu Y, Takai K, Zhou A, Eyob H, Balakrishnan S, Wang C-Y, Yaswen P, Goga A and Werb Z: Single-cell analysis reveals a stem-cell program in human metastatic breast cancer cells. Nature 526: 131-135, 2015.

66 De Vlaeminck Y, González-Rascón A, Goyvaerts C and Breckpot K: Cancer-Associated Myeloid Regulatory Cells. Front Immunol 7: 113, 2016.

67 Achyut BR and Arbab AS: Myeloid cell signatures in tumor microenvironment predicts therapeutic response in cancer. Onco Targets Ther 9: 1047-1055, 2016.

68 Leroi N, Lallemand F, Coucke P, Noel A and Martinive P: Impacts of ionizing radiation on the different compartments of the tumor microenvironment. Front Pharmacol 7: 78, 2016.

69 Ma Y, Yang H, Pitt JM, Kroemer G and Zitvogel L: Therapyinduced microenvironmental changes in cancer. J Mol Med (Berl) 94: 497-508, 2016.

70 Rabinovich GA and Conejo-García JR: Shaping the immune landscape in cancer by galectin-driven regulatory pathways. J Mol Biol 428: 3266-3281, 2016.

71 Fessler E, Dijkgraaf FE, De Sousa E Melo F and Medema JP: Cancer stem cell dynamics in tumor progression and metastasis: Is the microenvironment to blame? Cancer Lett 341: 97-104, 2013.

72 Ribeiro AL and Okamoto OK: Combined effects of pericytes in the tumor microenvironment. Stem Cells Int 2015: 1-8, 2015.

73 Shalapour S and Karin M: Immunity, inflammation, and cancer: an eternal fight between good and evil. J Clin Invest 125: 33473355, 2015.

74 Qin A, Coffey DG, Warren EH and Ramnath N: Mechanisms of immune evasion and current status of checkpoint inhibitors in non-small cell lung cancer. Cancer Med 5: 2567-2578, 2016.

75 Pizzi M, Boi M, Bertoni $\mathrm{F}$ and Inghirami G: Emerging therapies provide new opportunities to reshape the multifaceted interactions between the immune system and lymphoma cells. Leukemia 30: 1805-1815, 2016.

76 Li X, Nie J, Mei Q and Han W-D: MicroRNAs: Novel immunotherapeutic targets in colorectal carcinoma. World $\mathrm{J}$ Gastroenterol 22: 5317-5331, 2016.

77 Domschke C, Schneeweiss A, Stefanovic S, Wallwiener M, Heil J, Rom J, Sohn C, Beckhove P and Schuetz F: Cellular immune responses and immune escape mechanisms in breast cancer: Determinants of immunotherapy. Breast Care (Basel) 11: 102, 2016.

78 Yang Y: Cancer immunotherapy: harnessing the immune system to battle cancer. J Clin Invest 125: 3335, 2015.

79 Cerezo-Wallis D and Soengas M: Understanding tumor-antigen presentation in the new era of cancer immunotherapy. Curr Pharm Des 22: 6234-6250, 2016.

80 Fesnak AD, June $\mathrm{CH}$ and Levine BL: Engineered T cells: the promise and challenges of cancer immunotherapy. Nat Rev Cancer 16: 566-581, 2016. 
81 Guillerey C, Huntington ND and Smyth MJ: Targeting natural killer cells in cancer immunotherapy. Nat Immunol 17: 10251036, 2016.

82 El-Osta H, Shahid K, Mills GM and Peddi P: Immune checkpoint inhibitors: the new frontier in non-small-cell lung cancer treatment. Onco Targets Ther 9: 5101-5116, 2016.

83 Buchbinder E and Hodi FS: Cytotoxic T lymphocyte antigen4 and immune checkpoint blockade. J Clin Invest 125: 33773383, 2015.

84 Brahmer J, Reckamp KL, Baas P, Crinò L, Eberhardt WEE, Poddubskaya E, Antonia S, Pluzanski A, Vokes EE, Holgado E, Waterhouse D, Ready N, Gainor J, Arén Frontera O, Havel L, Steins M, Garassino MC, Aerts JG, Domine M, Paz-Ares L, Reck M, Baudelet C, Harbison CT, Lestini B and Spigel DR: Nivolumab versus docetaxel in advanced squamous-cell nonsmall-cell lung cancer. N Engl J Med 373: 123-135, 2015.

85 Karimkhani C, Gonzalez R and Dellavalle RP: A review of novel therapies for melanoma. Am J Clin Dermatol 15: 323$337,2014$.

86 Linardou $\mathrm{H}$ and Gogas $\mathrm{H}$ : Toxicity management of immunotherapy for patients with metastatic melanoma. Ann Transl Med 4: 272, 2016.

87 Tsiatas $\mathrm{M}$ and Grivas P: Immunobiology and immunotherapy in genitourinary malignancies. Ann Transl Med 4: 270, 2016.

88 Toh JWT, de Souza P, Lim SH, Singh P, Chua W, Ng W and Spring KJ: The potential value of immunotherapy in colorectal cancers: review of the evidence for programmed death-1 inhibitor therapy. Clin Colorectal Cancer 15: 285-291, 2016.

89 Zago G, Muller M, van den Heuvel $M$ and Baas P: New targeted treatments for non-small-cell lung cancer - role of nivolumab. Biologics 10: 103-117, 2016.

90 Herzberg B, Campo MJ and Gainor JF: Immune Checkpoint Inhibitors in Non-Small Cell Lung Cancer. Oncologist 22: 8188, 2016.

91 Duffy MM, Ritter T, Ceredig R and Griffin MD: Mesenchymal stem cell effects on T-cell effector pathways. Stem Cell Res Ther 2: 34, 2011.

92 Maria ATJ, Maumus M, Le Quellec A, Jorgensen C, Noël D and Guilpain P: Adipose-derived mesenchymal stem cells in autoimmune disorders: state of the art and perspectives for systemic sclerosis. Clin Rev Allergy Immunol 52: 234-259, 2016.

93 Zhao Y and Mazzone T: Human cord blood stem cells and the journey to a cure for type 1 diabetes. Autoimmun Rev 10: 103, 2010.

94 Ben-Ami E, Berrih-Aknin S and Miller A: Mesenchymal stem cells as an immunomodulatory therapeutic strategy for autoimmune diseases. Autoimmun Rev 10: 410, 2011.

95 Menard C, Pacelli L, Bassi G, Dulong J, Bifari F, Bezier I, Zanoncello J, Ricciardi M, Latour M, Bourin P, Schrezenmeier H, Sensebé L, Tarte K and Krampera M: Clinical-grade mesenchymal stromal cells produced under various good manufacturing practice processes differ in their immunomodulatory properties: standardization of immune quality controls. Stem Cells Dev 22: 1789-1801, 2013.

96 Najar M, Raicevic G, Fayyad-Kazan H, Bron D, Toungouz M and Lagneaux L: Mesenchymal stromal cells and immunomodulation: A gathering of regulatory immune cells. Cytotherapy 18: 160-171, 2016.
97 Gao F, Chiu SM, Motan DAL, Zhang Z, Chen L, Ji H-L, Tse $\mathrm{H}-\mathrm{F}, \mathrm{Fu}$ Q-L and Lian Q: Mesenchymal stem cells and immunomodulation: current status and future prospects. Cell Death Dis 7: e2062, 2016.

98 Waterman RS, Tomchuck SL, Henkle SL and Betancourt AM: A new mesenchymal stem cell (MSC) paradigm: polarization into a pro-inflammatory $\mathrm{MSC} 1$ or an Immunosuppressive MSC2 phenotype. PLoS One 5: e10088, 2010.

99 Waterman RS, Henkle SL and Betancourt AM: Mesenchymal stem cell 1 (MSC1)-Based therapy attenuates tumor growth whereas MSC2-treatment promotes tumor growth and metastasis. PLoS One 7: e45590, 2012.

100 Chan JL, Tang KC, Patel AP, Bonilla LM, Pierobon N, Ponzio $\mathrm{NM}$ and Rameshwar P: Antigen-presenting property of mesenchymal stem cells occurs during a narrow window at low levels of interferon-gamma. Blood 107: 4817-4824, 2006.

101 Liu Y, Han Z-P, Zhang S-S, Jing Y-Y, Bu X-X, Wang C-Y, Sun K, Jiang G-C, Zhao X, Li R, Gao L, Zhao Q-D, Wu M-C and Wei L-X: Effects of inflammatory factors on mesenchymal stem cells and their role in the promotion of tumor angiogenesis in colon cancer. J Biol Chem 286: 25007-25015, 2011.

102 Pitt JM, Marabelle A, Eggermont A, Soria J-C, Kroemer G and Zitvogel L: Targeting the tumor microenvironment: removing obstruction to anticancer immune responses and immunotherapy. Ann Oncol 27: 1482-1492, 2016.

103 Joyce JA and Pollard JW: Microenvironmental regulation of metastasis. Nat Rev Cancer 9: 239-252, 2009.

104 Castells M, Thibault B, Delord J-P and Couderc B: Implication of tumor microenvironment in chemoresistance: tumorassociated stromal cells protect tumor cells from cell death. Int J Mol Sci 13: 9545-9571, 2012.

$105 \mathrm{Mi}$ F and Gong L: Secretion of interleukin- 6 by bone marrow mesenchymal stem cells promotes metastasis in hepatocellular carcinoma. Biosci Rep, 2017. doi: 10.1042/BSR20170181. [Epub ahead of print]

106 Hanahan D and Weinberg RA: The hallmarks of cancer. Cell 100: 57-70, 2000.

107 Kachgal S and Putnam AJ: Mesenchymal stem cells from adipose and bone marrow promote angiogenesis via distinct cytokine and protease expression mechanisms. Angiogenesis 14: 47-59, 2011.

108 Chowdhury R, Webber JP, Gurney M, Mason MD, Tabi Z and Clayton A: Cancer exosomes trigger mesenchymal stem cell differentiation into pro-angiogenic and pro-invasive myofibroblasts. Oncotarget 6: 715-731, 2015.

109 Mele V, Muraro MG, Calabrese D, Pfaff D, Amatruda N, Amicarella F, Kvinlaug B, Bocelli-Tyndall C, Martin I, Resink TJ, Heberer M, Oertli D, Terracciano L, Spagnoli GC and Iezzi $\mathrm{G}$ : Mesenchymal stromal cells induce epithelial-to-mesenchymal transition in human colorectal cancer cells through the expression of surface-bound TGF- $\beta$. Int J cancer 134: 2583-2594, 2014.

110 McLean K, Gong Y, Choi Y, Deng N, Yang K, Bai S, Cabrera L, Keller E, McCauley L, Cho KR and Buckanovich RJ: Human ovarian carcinoma-associated mesenchymal stem cells regulate cancer stem cells and tumorigenesis via altered BMP production. J Clin Invest 121: 3206-3219, 2011.

111 Pine JK, Morris E, Hutchins GG, West NP, Jayne DG, Quirke $\mathrm{P}$ and Prasad KR: Systemic neutrophil-to-lymphocyte ratio in colorectal cancer: the relationship to patient survival, tumour biology and local lymphocytic response to tumour. Br J Cancer 113: 204-211, 2015 
112 de Aquino MTP, Malhotra A, Mishra MK and Shanker A: Challenges and future perspectives of T cell immunotherapy in cancer. Immunol Lett 166: 117-133, 2015.

113 Yuan Y: Modelling the spatial heterogeneity and molecular correlates of lymphocytic infiltration in triple-negative breast cancer. J R Soc Interface 12, 2014. doi: 10.1098/rsif.2014.1153. [Epub ahead of print]

114 Ogino S, Nosho K, Irahara N, Meyerhardt JA, Baba Y, Shima K, Glickman JN, Ferrone CR, Mino-Kenudson M, Tanaka N, Dranoff G, Giovannucci EL and Fuchs CS: Lymphocytic reaction to colorectal cancer is associated with longer survival, independent of lymph node count, microsatellite instability, and CpG island methylator phenotype. Clin Cancer Res 15: 64126420, 2009.

115 Goeppert B, Frauenschuh L, Zucknick M, Stenzinger A, Andrulis M, Klauschen F, Joehrens K, Warth A, Renner M, Mehrabi A, Hafezi M, Thelen A, Schirmacher P and Weichert W: Prognostic impact of tumour-infiltrating immune cells on biliary tract cancer. Br J Cancer 109: 2665-2674, 2013.

116 Galluzzi L, Vacchelli E, Bravo-San Pedro J-M, Buqué A, Senovilla L, Baracco EE, Bloy N, Castoldi F, Abastado J-P, Agostinis P, Apte RN, Aranda F, Ayyoub M, Beckhove P, Blay J-Y, Bracci L, Caignard A, Castelli C, Cavallo F, Celis E, Cerundolo V, Clayton A, Colombo MP, Coussens L, Dhodapkar MV, Eggermont AM, Fearon DT, Fridman WH, Fučíková J, Gabrilovich DI, Galon J, Garg A, Ghiringhelli F, Giaccone G, Gilboa E, Gnjatic S, Hoos A, Hosmalin A, Jäger D, Kalinski P, Kärre K, Kepp O, Kiessling R, Kirkwood JM, Klein E, Knuth A, Lewis CE, Liblau R, Lotze MT, Lugli E, Mach J-P, Mattei F, Mavilio D, Melero I, Melief CJ, Mittendorf EA, Moretta L, Odunsi A, Okada H, Palucka AK, Peter ME, Pienta KJ, Porgador A, Prendergast GC, Rabinovich GA, Restifo NP, Rizvi N, Sautès-Fridman C, Schreiber H, Seliger B, Shiku H, SilvaSantos B, Smyth MJ, Speiser DE, Spisek R, Srivastava PK, Talmadge JE, Tartour E, Van Der Burg SH, Van Den Eynde BJ, Vile R, Wagner H, Weber JS, Whiteside TL, Wolchok JD, Zitvogel L, Zou W and Kroemer G: Classification of current anticancer immunotherapies. Oncotarget 5: 12472-12508, 2014.

117 Di Nicola M, Carlo-Stella C, Magni M, Milanesi M, Longoni PD, Matteucci P, Grisanti S and Gianni AM: Human bone marrow stromal cells suppress T-lymphocyte proliferation induced by cellular or nonspecific mitogenic stimuli. Blood 99: 3838-3843, 2002.

118 Le Blanc K, Tammik C, Rosendahl K, Zetterberg E and Ringdén O: HLA expression and immunologic properties of differentiated and undifferentiated mesenchymal stem cells. Exp Hematol 31: 890-896, 2003.

119 Krampera M, Glennie S, Dyson J, Scott D, Laylor R, Simpson E and Dazzi F: Bone marrow mesenchymal stem cells inhibit the response of naive and memory antigen-specific $\mathrm{T}$ cells to their cognate peptide. Blood 101: 3722-3729, 2003.

120 Le Blanc K, Rasmusson I, Götherström C, Seidel C, Sundberg B, Sundin M, Rosendahl K, Tammik C and Ringdén O: Mesenchymal stem cells inhibit the expression of CD25 (interleukin-2 receptor) and CD38 on phytohaemagglutininactivated lymphocytes. Scand J Immunol 60: 307-315, 2004.

121 Meisel R, Zibert A, Laryea M, Göbel U, Däubener W and Dilloo D: Human bone marrow stromal cells inhibit allogeneic T-cell responses by indoleamine 2,3-dioxygenase-mediated tryptophan degradation. Blood 103: 4619-4621, 2004.
122 Klyushnenkova E, Mosca JD, Zernetkina V, Majumdar MK, Beggs KJ, Simonetti DW, Deans RJ and McIntosh KR: T cell responses to allogeneic human mesenchymal stem cells: Immunogenicity, tolerance, and suppression. J Biomed Sci 12: 47-57, 2005.

123 Aggarwal S and Pittenger MF: Human mesenchymal stem cells modulate allogeneic immune cell responses. Blood 105: 1815$1822,2005$.

124 Tse WT, Pendleton JD, Beyer WM, Egalka MC and Guinan EC: Suppression of allogeneic T-cell proliferation by human marrow stromal cells: implications in transplantation. Transplantation 75: 389-397, 2003.

125 Plumas J, Chaperot L, Richard M-J, Molens J-P, Bensa J-C and Favrot M-C: Mesenchymal stem cells induce apoptosis of activated T cells. Leuk Off J Leuk Soc Am Leuk Res Fund, UK 19: 1597-1604, 2005.

126 Glennie S, Soeiro I, Dyson PJ, Lam EW-F and Dazzi F: Bone marrow mesenchymal stem cells induce division arrest anergy of activated T cells. Blood 105: 2821-2827, 2005.

127 Rasmusson I, Ringdén O, Sundberg B and Le Blanc K: Mesenchymal stem cells inhibit lymphocyte proliferation by mitogens and alloantigens by different mechanisms. Exp Cell Res 305: 33-41, 2005.

128 Maccario R, Podestà M, Moretta A, Cometa A, Comoli P, Montagna D, Daudt L, Ibatici A, Piaggio G, Pozzi S, Frassoni $\mathrm{F}$ and Locatelli F: Interaction of human mesenchymal stem cells with cells involved in alloantigen-specific immune response favors the differentiation of $\mathrm{CD} 4+\mathrm{T}$-cell subsets expressing a regulatory/suppressive phenotype. Haematologica 90: 516-525, 2005.

129 Mellor A: Indoleamine 2,3 dioxygenase and regulation of T cell immunity. Biochem Biophys Res Commun 338: 20-24, 2005.

130 Selmani Z, Naji A, Gaiffe E, Obert L, Tiberghien P, RouasFreiss N, Carosella ED and Deschaseaux F: HLA-G is a crucial immunosuppressive molecule secreted by adult human mesenchymal stem cells. Transplantation 87: S62-S66, 2009.

131 Sioud M, Mobergslien A, Boudabous A and Fløisand Y: Mesenchymal stem cell-mediated $\mathrm{T}$ cell suppression occurs through secreted galectins. Int J Oncol 38: 385-390, 2011.

132 Gouveia de Andrade AV, Bertolino G, Riewaldt J, Bieback K, Karbanová J, Odendahl M, Bornhäuser M, Schmitz M, Corbeil $\mathrm{D}$ and Tonn T: Extracellular vesicles secreted by bone marrowand adipose tissue-derived mesenchymal stromal cells fail to suppress lymphocyte proliferation. Stem Cells Dev 24: 13741376, 2015.

133 Duffy MM, Pindjakova J, Hanley SA, McCarthy C, Weidhofer GA, Sweeney EM, English K, Shaw G, Murphy JM, Barry FP, Mahon BP, Belton O, Ceredig R and Griffin MD: Mesenchymal stem cell inhibition of T-helper 17 cell-differentiation is triggered by cell-cell contact and mediated by prostaglandin E2 via the EP4 receptor. Eur J Immunol 41: 2840-2851, 2011.

134 Tatara R, Ozaki K, Kikuchi Y, Hatanaka K, Oh I, Meguro A, Matsu H, Sato K and Ozawa K: Mesenchymal stromal cells inhibit Th17 but not regulatory T-cell differentiation. Cytotherapy 13: 686-694, 2011.

135 Thibaudin M, Chaix M, Boidot R, Végran F, Derangère V, Limagne E, Berger H, Ladoire S, Apetoh L and Ghiringhelli F: Human ectonucleotidase-expressing CD25(high) Th17 cells accumulate in breast cancer tumors and exert immunosuppressive functions. Oncoimmunology 5: e1055444, 2015. 
136 Wang W-B, Yen M-L, Liu K-J, Hsu P-J, Lin M-H, Chen P-M, Sudhir P-R, Chen C-H, Chen C-H, Sytwu H-K and Yen BL: Interleukin-25 mediates transcriptional control of PD-L1 via STAT3 in multipotent human mesenchymal stromal cells (hMSCs) to suppress Th17 responses. Stem cell reports 5: 392404, 2015.

137 Ghannam S, Pène J, Torcy-Moquet G, Jorgensen C and Yssel $\mathrm{H}$ : Mesenchymal stem cells inhibit human Th17 cell differentiation and function and induce a $\mathrm{T}$ regulatory cell phenotype. J Immunol 185: 302-312, 2010.

138 Chauhan S and Omoto M: Mechanisms of mesenchymal stem cell-mediated promotion of regulatory t cell function. Invest Ophthalmol Vis Sci 55: 1856, 2014.

139 Corcione A, Benvenuto F, Ferretti E, Giunti D, Cappiello V, Cazzanti F, Risso M, Gualandi F, Mancardi GL, Pistoia V and Uccelli A: Human mesenchymal stem cells modulate B-cell functions. Blood 107: 367-372, 2006.

140 Comoli P, Ginevri F, Maccario R, Avanzini MA, Marconi M, Groff A, Cometa A, Cioni M, Porretti L, Barberi W, Frassoni F and Locatelli F: Human mesenchymal stem cells inhibit antibody production induced in vitro by allostimulation. Nephrol Dial Transplant 23: 1196-1202, 2008.

141 Rafei M, Hsieh J, Fortier S, Li M, Yuan S, Birman E, Forner $\mathrm{K}$, Boivin MN, Doody K, Tremblay M, Annabi B and Galipeau J: Mesenchymal stromal cell derived CCL2 suppresses plasma cell immunoglobulin production via STAT3 inactivation and PAX5 induction. Blood 112: 4991-4998, 2008.

142 Tabera S, Pérez-Simón JA, Díez-Campelo M, Sánchez-Abarca LI, Blanco B, López A, Benito A, Ocio E, Sánchez-Guijo FM, Cañizo C and San Miguel JF: The effect of mesenchymal stem cells on the viability, proliferation and differentiation of Blymphocytes. Haematologica 93: 1301-1309, 2008.

143 Traggiai E, Volpi S, Schena F, Gattorno M, Ferlito F, Moretta $\mathrm{L}$ and Martini A: Bone marrow-derived mesenchymal stem cells induce both polyclonal expansion and differentiation of B cells isolated from healthy donors and systemic lupus erythematosus patients. Stem Cells 26: 562-569, 2008.

144 Youd M, Blickarz C, Woodworth L, Touzjian T, Edling A, Tedstone J, Ruzek M, Tubo R, Kaplan J and Lodie T: Allogeneic mesenchymal stem cells do not protect NZB ?? NZW F 1 mice from developing lupus disease. Clin Exp Immunol 161: 176-186, 2010.

145 Nauta AJ, Kruisselbrink AB, Lurvink E, Willemze R and Fibbe WE: Mesenchymal stem cells inhibit generation and function of both $\mathrm{CD} 34^{+}$-derived and monocyte-derived dendritic cells. J Immunol 177: 2080-2087, 2006.

146 Spaggiari GM, Capobianco A, Abdelrazik H, Becchetti F, Mingari MC and Moretta L: Mesenchymal stem cells inhibit natural killer-cell proliferation, cytotoxicity, and cytokine production: Role of indoleamine 2,3-dioxygenase and prostaglandin E2. Blood 111: 1327-1333, 2008.

147 Jiang X-X, Zhang Y, Liu B, Zhang S-X, Wu Y, Yu X-D and Mao N: Human mesenchymal stem cells inhibit differentiation and function of monocyte-derived dendritic cells. Blood 105: 4120-4126, 2005.

148 Spaggiari GM, Abdelrazik H, Becchetti F and Moretta L: MSCs inhibit monocyte-derived DC maturation and function by selectively interfering with the generation of immature DCs: Central role of MSC-derived prostaglandin E2. Blood 113: 6576-6583, 2009.
149 Klopp AH, Gupta A, Spaeth E, Andreeff M and Marini F: Concise review: Dissecting a discrepancy in the literature: do mesenchymal stem cells support or suppress tumor growth? Stem Cells 29: 11, 2011.

150 Liu T, Zhu K, Ke C, Yang S, Yang F, Li Z and Zhang Z: Mesenchymal stem cells inhibited development of lung cancer induced by chemical carcinogens in a rat model. Am J Transl Res 9: 2891-2900, 2017.

151 Griffin MD, Ryan AE, Alagesan S, Lohan P, Treacy O and Ritter T: Anti-donor immune responses elicited by allogeneic mesenchymal stem cells: what have we learned so far? Immunol Cell Biol 91: 40-51, 2013.

152 Otsu K, Das S, Houser SD, Quadri SK, Bhattacharya S and Bhattacharya $\mathrm{J}$ : Concentration-dependent inhibition of angiogenesis by mesenchymal stem cells. Blood 113: 4197-4205, 2009.

153 Secchiero P, Zorzet S, Tripodo C, Corallini F, Melloni E, Caruso L, Bosco R, Ingrao S, Zavan B and Zauli G: Human bone marrow mesenchymal stem cells display anti-cancer activity in SCID mice bearing disseminated non-Hodgkin's lymphoma xenografts. PLoS One 5: e11140, 2010.

154 Wang C, Chen J, Wen P, Sun P and Xi R: Stem Cell Niche. In: Regenerative Medicine - from Protocol to Patient. Cham, Springer International Publishing, pp. 57-85, 2016.

155 Ling X, Marini F, Konopleva M, Schober W, Shi Y, Burks J, CliseDwyer K, Wang RY, Zhang W, Yuan X, Lu H, Caldwell L and Andreeff M: Mesenchymal Stem cells overexpressing ifn- $\beta$ inhibit breast cancer growth and metastases through Stat 3 signaling in a syngeneic tumor model. In: Cancer Microenvironment, pp. 83-95, 2010.

156 Jazedje T, Ribeiro AL, Pellati M, de Siqueira Bueno HM, Nagata G, Trierveiler M, Rodrigues EG and Zatz M: Human mesenchymal stromal cells transplantation may enhance or inhibit 4t1 murine breast adenocarcinoma through different approaches. Stem Cells Int 2015: 796215, 2015.

157 Long X, Matsumoto R, Yang P and Uemura T: Effect of human mesenchymal stem cells on the growth of HepG2 and Hela cells. Cell Struct Funct 38: 109-121, 2013.

158 Assoni A, Coatti G, Valadares MC, Beccari M, Gomes J, Pelatti M, Mitne-Neto M, Carvalho VM and Zatz M: Different donors mesenchymal stromal cells secretomes reveal heterogeneous profile of relevance for therapeutic use. Stem Cells Dev 26: 206-214, 2017.

159 Duscher D, Rennert RC, Januszyk M, Anghel E, Maan ZN, Whittam AJ, Perez MG, Kosaraju R, Hu MS, Walmsley GG, Atashroo D, Khong S, Butte AJ and Gurtner GC: Aging disrupts cell subpopulation dynamics and diminishes the function of mesenchymal stem cells. Sci Rep 4: 7144, 2014.

160 Ranganath SH, Levy O, Inamdar MS and Karp JM: Harnessing the mesenchymal stem cell secretome for the treatment of cardiovascular disease. Cell Stem Cell 10: 244-58, 2012.

161 Bedard PL, Hansen AR, Ratain MJ and Siu LL: Tumour heterogeneity in the clinic. Nature 501: 355-364, 2013.

162 Pelatti MV, Gomes JPA, Vieira NMS, Cangussu E, Landini V, Andrade T, Sartori M, Petrus L and Zatz M: Transplantation of human adipose mesenchymal stem cells in nonimmunosuppressed GRMD dogs is a safe procedure. Stem Cell Rev Reports 12: 448-453, 2016.

163 Mardones R, Jofré CM, Tobar L and Minguell JJ: Mesenchymal stem cell therapy in the treatment of hip osteoarthritis. J hip Preserv Surg 4: 159-163, 2017. 
164 Wang Z, Luo Y, Chen L and Liang W: Safety of neural stem cell transplantation in patients with severe traumatic brain injury. Exp Ther Med 13: 3613-3618, 2017.

165 Wang X, Yin X, Sun W, Bai J, Shen Y, Ao Q, Gu Y and Liu Y: Intravenous infusion umbilical cord-derived mesenchymal stem cell in primary immune thrombocytopenia: A two-year followup. Exp Ther Med 13: 2255-2258, 2017.

166 Vulliet PR, Greeley M, Halloran SM, MacDonald KA and Kittleson MD: Intra-coronary arterial injection of mesenchymal stromal cells and microinfarction in dogs. Lancet 363: 783-784, 2004.

167 Kang MH and Park HM: Evaluation of adverse reactions in dogs following intravenous mesenchymal stem cell transplantation. Acta Vet Scand 56: 16, 2014.
168 Quimby JM, Webb TL, Habenicht LM and Dow SW: Safety and efficacy of intravenous infusion of allogeneic cryopreserved mesenchymal stem cells for treatment of chronic kidney disease in cats: results of three sequential pilot studies. Stem Cell Res Ther 4: 48, 2013.
Received May 22, 2017

Revised June 23, 2017

Accepted July 5, 2017 